\title{
Performing whole-exome sequencing in Bardet-Bield syndrome
}

\author{
S Castro-Sánchez ${ }^{1,2^{*}}$, M Alvarez-Satta ${ }^{1,2}$, D Valverde ${ }^{1,2}$ \\ From Cilia 2014 - Second International Conference \\ Paris, France. 18-21 November 2014
}

\section{Objective}

Bardet-Biedl syndrome (BBS) is a rare disease characterized by a high genetic heterogeneity, accounting for $75 \%$ of affected families. As part of the next-generation technology, whole-exome sequencing (WES) allows all exons of the genome to be sequenced at once. Here we show the use of WES as a useful approach in BBS families in which mutations in predominant genes have been discarded.

\section{Methods}

We studied the exome of 15 unrelated patients clinically diagnosed with BBS. For this purpose, we used the Nimblegen SeqCap v3 (64Mb) kit for exome capture, followed by the use of Illumina HiSeq 2000 sequencer, with a mean coverage per sample $>50 \mathrm{X}$. Once the sequencing data alignment and variant calling were made, we carried out a filtering strategy to identify candidate mutations responsible for the disorder, which need to be confirmed by direct sequencing. Segregation analyses were performed when possible.

\section{Results}

This approach, focused on evaluating mutations in genes involved in the pathology (all $B B S$ genes, and also ALMS1 gene), has allowed us to diagnose 4 families, identifying 5 potential disease-causing mutations representing 3 different known genes (BBS2, BBS5 and $A L M S 1) .4$ of these changes were novel mutations and segregation studies confirmed the carrier state in parents. In the remaining families, we have selected some candidate genes which are under evaluation.

'Biochemistry, Genetics and Immunology, University of Vigo, Vigo, Spain Full list of author information is available at the end of the article

\section{Conclusion}

We consider this is a good and economically worthwhile strategy when predominant mutations have been discarded in the analysed population. Moreover, it allows us to reduce diagnostic time and offers the possibility to identify novel candidate genes.

\section{Authors' details}

${ }^{1}$ Biochemistry, Genetics and Immunology, University of Vigo, Vigo, Spain. ${ }^{2}$ Instituto de Investigación Biomédica Ourense-Pontevedra-Vigo (IBI), Vigo, Spain.

Published: 13 July 2015

\section{doi:10.1186/2046-2530-4-S1-P11}

Cite this article as: Castro-Sánchez et al:: Performing whole-exome sequencing in Bardet-Bield syndrome. Cilia 2015 4(Suppl 1):P11.

\section{Submit your next manuscript to BioMed Central and take full advantage of: \\ - Convenient online submission \\ - Thorough peer review \\ - No space constraints or color figure charges \\ - Immediate publication on acceptance \\ - Inclusion in PubMed, CAS, Scopus and Google Scholar \\ - Research which is freely available for redistribution

C Biomed Central

C 2015 Castro-Sánchez et al. This is an Open Access article distributed under the terms of the Creative Commons Attribution License (http://creativecommons.org/licenses/by/4.0), which permits unrestricted use, distribution, and reproduction in any medium, provided the original work is properly cited. The Creative Commons Public Domain Dedication waiver (http://creativecommons.org/ publicdomain/zero/1.0/) applies to the data made available in this article, unless otherwise stated. 